\title{
Three-dimensional cell culture, opportunities and challenges for bioprocess engineers
}

\section{Samille Henriques Pereira, Denise Soares de Moura Coutinho, Ana Flávia de Oliveira Gonçalves de Matos, Willer Ferreira da Silva Junior and Daniela Leite Fabrino}

Universidade Federal de São João Del Rei. Campus Alto Paraopeba. Rodovia MG-443, km 7. Fazenda do Cadete. Ouro Branco-MG. Brazil (CEP 36420-000). Email: samillehenriques@gmail.com.

\begin{abstract}
Two-dimensional cell culture (2D) is the most used technique in studies of mass production of proteins and vaccines; however, this technique is quite limited, since cells lose their phenotypic characteristics when cultured in monolayer. As an alternative, three-dimensional cell culture (3D) allowed cells to be cultured within an environment closer to their natural one, keeping in that way, their physiologic characteristics. When grown in this kind of system, cells form structures called multicellular spheroids, which present in their cores: cellular heterogeneity, microenvironment formation, and different expositions to several factors, such as nutrients and oxygen. This technique has revolutionized researches on drug development and its mechanism of action, since the results obtained in 3D cell culture are more realistic than the ones arisen from $2 \mathrm{D}$ cell culture. Recently, there have been developed many 3D cell culture methodologies, however, it misses technology to scale up the biomass growth, which is a great challenge for bioprocess engineers (BE). Therefore, this review aimed to show the technical reality of 3D cell culture and how such professionals can apply their engineering and life science knowledge to improve and develop new technologies that make the use of 3D cell culture feasible and widely used by biotechnological industries.
\end{abstract}

Keywords: Cell culture; Three-dimensional; Spheroids; Bioprocess engineer.
Received

November 9, 2016

Accepted

December 23, 2016

Released

December 31, 2016

Open Acess Full Text Article

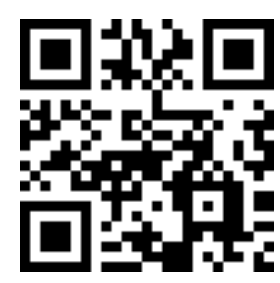

ORCID

(1) 0000-0002-3914-2634

Samille Henriques Pereira

(1) 0000-0002-2948-4315

Denise Soares de Moura Coutinho

(1) 0000-0003-4042-5655

Ana Flávia de Oliveira Gonçalves de Matos

(1) 0000-0003-4255-3431

Willer Ferreira da Silva Junior

(D) 0000-0002-3412-1375

Daniela Leite Fabrino 


\section{Introduction}

Cell culture provide means to maintain cell alive within controlled laboratorial conditions. The use of this technique led to a better understanding of cells' molecular mechanisms, resulting in important scientific advances in the fields of vaccine production and tumor cell biology (Luisi et al., 2004).

Over the past 15 years, the use of mammalian cells has contributed to the leverage of methods in diagnosis, therapy and processes that improve the quality of life (Moraes et al., 2007), as can be seen in the industrial environment cell culture, along with bioprocess engineers (BE) knowledge, enables large scale production of pharmaceuticals, vaccines, cosmetics, in addition to in vitro cell tissue production, which helps the regeneration of tissues and organs (Carvalho, 2010; Barbosa et al., 2015).

Mammalian cells cultured in flat cell culture flasks or Petri dishes are in nonnatural living conditions and since the space where they are grown is two-dimensional they reproduce monolayer tissues, which leads to losses of phenotypical characteristics due to reduction of biochemical signals exchange, which are necessary to express some genes, and the absence of cytokines, adhesion molecules and hormones involved in the cell-cell and cell-ECM contacts (Dutta and Dutta, 2009; Pampaloni et al., 2007).

Oppositely to 2D, 3D cell culture does not show significant lack of those molecules and therefore represents better in vitro conditions, that has revolutionized the comprehension of cell's behavior (Elsdale and Bard, 1972; Pampaloni et al., 2007), this approach has the potential to enhance the physiologic relevancy of bioassays and enable the modeling of biosystems formed by mammalian cells and the improvement of drugs' citotoxicicity and bioactivity assays may reduce the amount of animal testing carried out by pharmaceutical industries and governmental institutions (Ravi et al., 2015; Dhaliwal, 2012). Nonetheless, this technique has still not been implemented in industries due to lack of technology suitable to large scale production within feasible costs (Justice et al., 2009).

Based on what was presented above, one can conclude that a deeper understanding about both cell culture and its engineering aspects, as well as a literature review on new technologies for three-dimensional cell growth is necessary, which is brought by this paper.

\section{culture}

\section{History of three-dimensional cell}

It took about 30 years to have papers about 3D cell culture published after the Alex Carrel's discover. Such papers were authored by Johannes Holtfreter, Aron Arthur Moscona, and Joseph Leighton (Amaral and Machado-Santelli, 2011).

Johannes Holtfreter was an icon of the embryology field and his experiments contributes to the three-dimensional cell culture development as it demonstrated that there was a certain affinity between tissues of organisms, evincing the presence of cellular adherence. In Holtfreter's experiments, embryonic leaflets were separated, and those, which were put into contact with some tissue, again had their cells regrouped in their respective leaflets, with certain degree of differentiation, according to their embryonic origin. In 1944, Holtfreter created a method to generate spherical cellular aggregates by adding agar on the surface of Petri dishes, avoiding the non adherence of cells to the bottom of the plates. In 1947, he made changes in the method, reducing the interaction of cells with substrate even more (Byrnes, 2009).

Joseph Leighton, 1921-1999, highlighted the fact that monolayer cellular growth was a far-fetched representation of organisms, and with his pioneering studies shed light into the field such as the development of the sponge-matrix culture system which used a fibrin clot reinforced by cellulose sponge as substrate, what allowed a better organization of tissue structures once the cellulose sponge prevented the breakdown of the fibrin clot as the cells grew (Schaeffer, 1999). 
In 1954, Leighton pointed in his paper that: a three-dimensional arrangement enables cells to migrate towards any direction; 3D system promotes the increase of cellular surface; such system makes possible the diffusion of nutrients, which produces changes in cell's morphologythat may tagger processes related to tissual differentiation; the diffusion present in the inner of aggregates might grant the ability of retain factors secreted by cells (reviewed in Amaral, 2010).

On the other hand, Aron Arthur Moscona analyzed how individual embryonic cells organized themselves to give origin to tissues and organs. In one of his experiments in 1957, he realized that when tissues of different organisms were separated enzymatically, cells from distinct organs did not mingle between them; cells derived from poultry embryonic cartilage, for example, could be joined to one another, but they did not mingle with kidney cells; he also discovered that membrane-surface molecules of cells from a certain organism can have affinity to molecules from another organism (chimeras) and came up with the idea of cell-cell recognition (reviewed in Amaral and Machado-Santelli, 2011).

Corroborating studies about the importance of 3D structure in cell culture, Elsdale and Bard (1972) published a paper about the importance of collagen-based substrates on cells' behavior during cultivation in laboratory.

In a poetic quotation, a question that has still been theme of discussion in science was classically thrown:

Snatched from a life of obscurity and installed in contemporary glass and plastic palaces, cells are in danger of becoming Pygmalion's protégés Housed in more traditional residences constructed of water and collagen instead of plastic or glass, do cells lead primitive, less cultured lives? (Elsdale and Bard, 1972).

Thereby, it was established the importance of extracellular matrix and 3D cellular in in vitro experiments.

\section{Extracellular Matrix (ECM)}

The ECM of a certain tissue is a complex mixture of proteins, glycoproteins, lipids, glycolipids and mucopolysaccharides. It contains three important fibrous proteins: collagen, elastin and fibronectin disperse in a hydrated gel formed of glycosaminoglycan chain networks. All those molecules are secreted locally by cells which are in contact with extracellular matrix (Alves and Guimarães, 2010). These proteins form a specific composition of biochemical compounds and defined geometric structures that stimulate cellular responses, such as differentiation (Justice et al., 2009). Table 1 summarizes some of the ECM's function.

ECM-based materials have been used in tissue engineering and regenerative medicine. It has been shown that these materials, when properly prepared, can act as inductive models in constructive remodeling (Brown and Badylak, 2014). The comprehension of ECM which surrounds cells in vivo makes the development of researches on 3D cell culture possible (Justice et al., 2009).

\section{Techniques utilized in 3D culture}

This study reviews the main techniques in three-dimensional cell culture, pointing out its advantages and disadvantages. Currently, 3D cell cultures can be obtained through the production of spheroids, use of scaffolds and matrix formation.

\section{Spheroid formation}

The procedures to form spheroids are consisted of using cells that are induced to formation of self-organized spherical agglomerates that secrete their own ECM (Vinci et al., 2012).

\section{Hanging drop}

In this technique, one little sample of cellular suspension is pipetted into special well plates that are put up side down and the cell suspensions form suspended drops, held in such way by superficial tension. Cells accumulate on the edges of 
the drops and proliferate, resulting in spheroids with consistent sizes and shapes (Kelm et al., 2003).

The plate contains both a lid and a bottom tray that are used to keep the culture's sterility and reduce water evaporation, respectively. Wells enable one to manipulate media and spheroids. In addition, the plate has water reservoirs in its peripheries, which also reduces evaporation (Breslin and O’Driscoll, 2013).

Spheroids can be analyzed through colorimetric methods, fluorescence and luminescence assays by using spectrophotometers that analyze all wells. Microscopic analysis of spheroids can be done directly, using a transparent plate, lid and bottom tray set, or by collecting samples from cells suspension and processing it for electrical and spectrophotometric techniques. This analysis can be carried out in automated platforms, which also offer simplified procedures to manipulate liquids, and is compatible with High-Throughput Screening (HTS) instrumentation (Tung et al., 2011).

Table 1. Extracellular matrix’s function.

\begin{tabular}{|c|c|}
\hline Function & Mechanism \\
\hline To act as adhesive substrate. & $\begin{array}{l}\text { - It forms trails to guide migratory cells. } \\
\text { - It uses gradient of concentration for haptotactic migration. }\end{array}$ \\
\hline To provide cells/tissue with structure. & $\begin{array}{l}\text { - Tissue formation. } \\
\text { - It provides organs in development phase with integrity } \\
\text { and elasticity. }\end{array}$ \\
\hline To sequester and store growth factors. & $\begin{array}{l}\text { - It contributes to the regulation of temporal space of } \\
\text { growth factor release. } \\
\text { - It organizes morphogenic gradient. } \\
\text { - It mediates the release of factors in the presence of forces, } \\
\text { mediated cells, and/or proteolysis. }\end{array}$ \\
\hline $\begin{array}{l}\text { Sensors and transducers of mechanical } \\
\text { signals. }\end{array}$ & $\begin{array}{l}\text { - It defines permissive and instructive mechanical } \\
\text { properties for cellular differentiation. } \\
\text { - It activates intracellular signaling through interactions } \\
\text { with cell surface receptors. } \\
\text { - It activates the cytoskeleton machinery and acts } \\
\text { synergically along with growth factors promoting cellular } \\
\text { growth. }\end{array}$ \\
\hline
\end{tabular}

Font: Adapted from Rozario and Desimone (2010).

In general, this method is the simplest and most commonly used in 3D cell culture. However, there are some limitations, such as the uncontrollable growth of spheroids' size, what leads to restrictions to oxygen and nutrients diffusion, accumulation of toxic metabolites in the inner part of the cell culture; that could result in necrosis in that region (Astashkina and Grainger, 2014). The superficial tension that keeps spheroids bonded to media's surface can hold up to 50 $\mu \mathrm{l}$ of cell suspension and offer some resistance to aspirating media without disturbing the spheroids (Kurosawa, 2007).

\section{Forced floating}

Oppositely to hanging drop, this method consists of forming cellular aggregate suspension through centrifugation. A non-adherent substrate, such as Polyhydroxyethylmethacrylate (PHEMA), or poly-Np-vinylbenzyl-Dgluconamide, is added to the media and generates a thin layer on the cell culture dish's surface. Cells are grown on such substrate instead of adhering to the surface 
and then, when they are submitted to stirring, they aggregate to one another, giving origin to spheroids (Lin and Chang, 2008; Fennema et al., 2013).

The forced floating method is relatively simple and able to generate the same number of cells in each well, creating morphologically-homogen spheroids. Such homogeinity is affected by the type of cell, target density, media composition and static stirring (Breslin and O’Driscoll, 2013; Lin and Chang, 2008).

Some desadvantages of this method are the time and workforce spent to coat the plates. As alternative, pre-coated plates, available in the market, might be used, however, an increase on the process' total cost should be taken into account (Ivascu and Kubbies, 2006).

\section{Matrix generation}

Another 3D cell culture technique is the formation of gels and sponges that uses purified molecules from ECM and biopolymers to reproduce in vivo conditions. Matrigel ${ }^{\mathrm{TM}}$, rich in extracellular proteins, such as collagen and laminin, plus to growth factors and enzymes, and AlgiMatrix $^{\mathrm{TM}}$, based on lyophilisated alginate, which allow cells to penetrate into the pores and secrete ECM endogenous compounds providing cell culture with adequate morphology and structure are good examples of this (Justice et al., 2009).

Synthetic gels, such as polyethylene glycol (PEG), which are modified to obtain the desired characteristics through combination of both natural and synthetic materials, by incorporating several proteins or other molecules into the matrix can also be done ( $\mathrm{Li}$ et al., 2012). Yet gels can be combined with other methods, such as spheroids culture, scaffolds and microchips (Lowe et al., 2014).

\section{Use of scaffolds}

Cells cultured in pre-manufactured scaffolds can migrate throughout its fibers and adhere to these structures. The interstitial space between fibers is filled by cells generating three-dimensional cellular structures (Breslin and O’Driscoll, 2013).
Many scaffolds have been developed by using a wide variety of biomaterials of different porosity, permeability and mechanical behavior in order to simulate the ECM's unique characteristics as much as possible (Lee et al., 2008). Natural polymers are more compatible with ECM; however, they do not show mechanical resistance as good as synthetic polymers do, on the other hand, synthetic polymers are easily adaptable to target porosity and have reproducible mechanical and physical properties (Maltman and Przyborski, 2010; Dhaliwal, 2012).

Among the properties desired to maintain phenotypical regulation in nonnatural ECM are i) capacity to retain water; ii) porosity that enables cells to grow and organize themselves into 3D structures; iii) biodegradability, to create void spaces for new cells; iv) connectivity between pores, to allow free passage of oxygen and nutrients flow towards cells' surrounding spaces (Dutta and Dutta, 2009).

\section{Microcarriers}

Microcarriers are 3D supports made of synthetic (plastic, silicone) or natural (collagen, cellulose, and dextran) materials, which provide adherent cells with surface to grow. They greatly increase surface of cell growing per volume, especially when macroporous microcarriers are used, allowing cells to proliferate inside the macropores (Kuystermans and Al-Rubeai, 2011), like in scaffolds.

The pores' size plays a big role, allowing both cell proliferation, cell protection against shear forces and media flow through pores, many cells, such as CD34+, erythroid, iPS and stem cells, have been cultured in this system and the results have shown its advantage over 2D cell culture (Kumar and Starly, 2015).

Nevertheless, if cells are the process product, their removing from inside the beads may be difficult, requiring addition of phosphate and reduction of $\mathrm{Mn}^{2+}, \mathrm{Ca}^{2+}$ and $\mathrm{Mg}^{2+}$, or trypsin and ethylenediaminetetraacetic acid, or collagenase combined with salts, depending 
on the beads (Kuystermans and Al-Rubeai, 2011).

\section{Bioreactors}

Due to many applications of 3D cell culture and the increasing adoption of researchers to this system as more accurate cellular models (Haycock, 2011), mass production of cells in three-dimensional environment is needed. In the obtainment of "cell based regenerative medicine therapy", for example, the step that requires more time and money to be concluded is the manufacturing of high amounts cells, based on 2D culture techniques currently employed in this phase. To achieve high cell concentration, optimal biochemical and physical-chemical conditions of culture should be controlled in a sterile environment, which can be obtained through bioreactor of adequate scale (Kumar and Starly, 2015).

Bioreactors are vessels where transformation of matter takes place, catalyzed by living cells or enzymes, usually under controlled conditions. Traditionally, bioreactors are cylindrical and agitated by impellers which are responsible for breaking air bubbles and homogenizing biomass, nutrients, products, heat and air along the vessel. However, due to the higher sensibility of mammalian cells to shear, such conventional reactor has been replaced by new bioreactor designs developed for 3D mammalian cell culture. Shear could prevent cells from forming spheroids, for example (Williams, 2002).

For larger spheroid production, methods similar to those based on rotatory cultivation can be used; that is, spinner flasks and rotational culture. The spheroids formed in both methods are relatively uniform when compared to stationary cultures (Lin and Chang, 2008). Other kinds of reactors are also available, as it is presented below.

Stirred Tank Reactor (STR). STR is one of the most common type of reactor and can be operated either in batch, fedbatch or continuous mode. It is usually formed by a glass or stainless steel cylindrical vessel (although single use systems have been used lately for cGMP industrial production) equipped with baffles near the vessels' walls to avoid formation of vortices, impeller for homogenization, gas sparger for introduction of gases, heat exchanger to control the reactor's temperature, tubing system to inject solutions and extract samples, and probes for physical-(bio) chemical measurements (Garcia-Ochoa et al., 2011; GE Healthcare Life Science, 2016).

Some advantages of STR are its availability in the market in several scales, great knowledge about its function and ease to model. Nonetheless, for 3D cell culture, it is necessary to add microcarriers or scaffolds into the reactor, so that cells can adhere to three dimensional supports, and use impellers that result in less shear (e.g. marine and pitched blade impellers), especially when spheroids are directly poured into the reactor (Kumar and Starly, 2015).

Shear forces arise from impellers because of eddies -areas of rotational flow, usually right behind the impeller, characteristic of turbulent flow formation, which are also responsible for increasing dispersion of substances along the reactor, and hence homogeneity. If microcarriers or spheroids have diameter bigger than the characteristic dimension of the smallest eddies, the particle is bound to suffer damages from shear. Eddies characteristic dimension are reduced when tip speed and impeller diameter are increased and increased with rise of fluid's viscosity; its dimension varies from 30 to $100 \mu \mathrm{m}$ for low viscosity media. Therefore, Rushton turbine is the less indicated for mammalian cell culture, since it is the most effective in causing fluid turbulence (Doran, 1995).

Another great source of shear are the bursting bubbles of air coming out of air sparger; although the oxygen uptake rate in mammalian cell culture is rather lower than in microbial cultivation (Kuystermans and Al-Rubeai, 2011), air flow rate should be set as low, but high enough to result in volumetric oxygen mass transfer constant $\left(\mathrm{k}_{\mathrm{L}} \mathrm{a}\right)$ higher than critical $\mathrm{k}_{\mathrm{L}} \mathrm{a}\left(\mathrm{k}_{\mathrm{L}} \mathrm{a}_{\text {Critc. }}\right)$, that is, the volumetric oxygen mass transfer constant at which cellular oxygen uptake 
rate becomes equal to the rate of oxygen transfer from the gas to liquid phase (Doran, 1995). In this case, sparger pores should be very small to reduce the size of bubble size and then, increase $\mathrm{k}_{\mathrm{L}} \mathrm{a}$.

Spinner flasks. Spinner flasks are used at lab scale in low density cell culture and when mixing and oxygen demand are relatively low.

This method consists in a flask containing a stirrer, which is responsible for continuously mixing the cellular suspension. The spheroid yield is dependant on flasks' size; they usually host a volume ten times bigger than systems used in stationary culture, which leads to higher biomass and biomolecules production in lab scale. Its design enables the media to be constantly altered, making the cultivation last for longer. In addition, the continuous movement present into the flasks is fundamental to help on the transport of nutrients throughout the cell culture media (Hsiao et al., 2012; Breslin and O’Driscoll, 2013).

One disadvantage of this method is the production of non-uniform spheroids. To overcome this problem, spheroids can be formed through forced floating and then, transferred to spinner flasks, leading to similarly sided spheroids and media where nutrients and oxygen are easily controlled throughout long periods (Breslin and O’Driscoll, 2013).

Rotational culture system. The rotational vessel developed by NASA in 1992 was projected to create a low gravity environment in order to apply a low shear force on cells. The system comprises a culture chamber that slowly rotates over a horizontal axis containing a cylinder with porous wall that delivers oxygen to media; this constant movement prevents cells from adhering to the chamber's walls and the rotational speed can be adjusted in order to meet optimal conditions (Winkenwerder et al., 2003).

Rotational culture system has been proved to me more efficient when its diameter is larger and its length is shorter, as well as has been used in expansion of many cell types, such as human embryonic palatal mesenchymal pre-osteoblasts, epidermal and umbilical cord blood mononuclear cells. However, this system presents problems with scale up, due to volume limitation (Kumar and Starly, 2015).

Wave bioreactor. Wave bioreactor was launched in the 1990's (GE Healthcare Life Science, 2016) and is composed by a single-use bag placed on a support that is continuously swayed. This movement is responsible for mixing the culture media (up to $50 \%$ of bag's volume), guaranteeing cell and nutrients homogeneity with very low shear effects, which makes this reactor an excellent choice for spheroids culture. Gas exchange occurs through the contact of cell culture media with the air injected into the bag in the liquid-gas interface (Kuystermans and Al-Rubeai, 2011).

This system has the advantages of being single-use (time and cost reduction), making its automation easy and offering the possibility of being operated in batch, fedbatch, continuous or perfusion mode (Kuystermans and Al-Rubeai, 2011). On the other hand, scale up of wave bioreactor for more that $100 \mathrm{~L}$ is challenging and may be carried out through increasing the number of reactors, which demands more space in manufacturing suits, due to reactor's geometry, in addition, for high volumes and cell density, mass transfer may be inefficient (Kumar and Starly, 2015). Likewise in STR, microcarriers are necessary for 3D cell culture of adherent cells when spheroids are not directly inoculated into the reactor.

\section{Hollow fiber bioreactor (HFB).} $\mathrm{HBF}$ is a continuous reactor where the transformation of matter takes place along the direction where the flow containing substrates passes through, creating a gradient of concentration., very similar to hollow fiber filters or shell-and-tube heat exchangers, they contain porous hollow fibers involved by a shell, which forms intra (inside the fiber) and extra (outside fiber)-capillary spaces. Cells can be inoculated and cultured in the extra- 
capillary zone whilst media flows throughout intra-capillary zone; this mode mimics blood vessels and tissue, and hence, both oxygen and nutrients must pass through porous fiber walls and reach the cells through diffusion (Kumar and Starly, 2015).

If on one hand hollow fiber bioreactor mimics blood vessel leading to very low shear stress and large surface of contact for cellular growth (Martin et al., 2005), on the other hand mass transfer may limit cell expansion (Kumar and Starly, 2015), since the driving force of particles' movement towards cells is only diffusion; at high cell density, it is bound that oxygen do not reach inner cells, causing necrosis..

Packed-bed bioreactor. Packedbed bioreactors are columns filled with stationary phase (microcarriers, microcapsules, fibers, scaffolds) where cells are immobilized. Fresh and oxygenated media passes through packed bed, feeding cells and flows out of reactor. Different researchers have been successfully cultured into this system (Sailon et al., 2009; Goepfert et al., 2011; Kumar and Starly, 2015).

Packed-bed systems show advantages on mass transfer when scaffolds are used as fixed beds in comparison to static culture, STR, spinner flasks and wave bioreactors. In these last models, scaffolds must be limited to about $4 \mathrm{~mm}$ thickness to avoid necrosis in their cores, since transport of nutrients to the inner part happens only through natural convection and diffusion (in macroporous matrixes); on the other hand, in fixed bed reactors, nutrients and oxygen are forced into the scaffold (Sailon et al., 2009). Alike HBF, packed-bed bioreactors have the cons of presenting gradient of concentration and difficulties in biomass analysis (Kumar and Starly, 2015). Other challenge in engineering aspects of reactor is pressure drop due to stationary phase.

Mechanical force systems. Bioreactor in tissue engineering goes beyond stirring cells. They are necessary in order to obtain standardized seeding inside the 3D matrix, provide cells with 3D environment, control process parameters and mechanically stimulate cells. Cardiac and bone tissues have been stimulated by shear cause by flow rate; blood and heart valves have been cultured under differential pressure, while skeletal muscle tissue has been cultured under physical tension. These stimuli are another condition necessary to cells differentiation and proliferation (Wendt, 2009).

The reactors that provides mechanical forces offers a big challenge to professionals from the field, since they are quite different from traditional bioreactors and require special tools and equipment to provide cells with the adequate physical stimulus. In addition to that, the frequency of such stimuli should also be properly established in order to obtain the desired cell differentiation.

The comparison among these bioreactors can be seen at the Table 2 .

\section{Application of 3D cell culture}

\section{Tissue engineering}

Tissue engineering deals with the development of alternative means for implants, prosthesis and grafts, used in regenerative medicine, aiming to regenerate wounded tissue faster and better (Tavares, 2011). However, in order to achieve it, one should pay attention on two variables at the same time: cells and the materials used to simulate ECM.

It is possible to grow cells (autologous, isologous, allogeneic or xenolog cells), and implant it in patients through infusion; this application has the limitation of immunological rejection, due to the use of cells from different individuals, besides the cells' difficulty in maintaining their characteristics in vitro, even so, autologous implant presents advantages over organ transplant, since a small number of cells from the donator is required (Santos Junior and Wada, 2007).

Regarding materials, new technologies with capacity of interacting with biological tissues have been developed to serve as structure for in vitro cellular growth, what helps cells organization and development of the tissue, so to embed a 
certain material into human body, requirements must be met: be biocompatible and functional, nontoxic, easy to be sterilized and present satisfactory mechanical properties, depending on the application's propose. The biomaterial ought to ensure not only the tissue's regeneration, but also that there will not be any side effect to human body, in long-term period (Burg et al., 2000).

\section{Pharmacological application}

3D cell culture has the potential to improve, in great extend, drug screening and the identification of both toxic and inefficient substances. In addition, it may reduce the number of animal-based assays, which considerably lessens either costs or complexity of experiments (Pampaloni et al., 2009; Elliott and Yuan, 2010).

Most tested drugs, as well as many assays utilized to evaluate cytotoxicity, rely on the diffusion of molecules inward and outward the matrix. However, the transport and diffusion of drugs might be affected by some factors, such as potential interactions between the drug and the matrix, matrix's low porosity and short period of contact between cells and the drug (Astashkina and Grainger, 2014).

Table 2. Advantages and disadvantages of different 3D cell culture techniques.

\begin{tabular}{|c|c|c|}
\hline Technique & Advantage & Disadvantage \\
\hline Hanging drop & $\begin{array}{l}\text { - Relatively simple. } \\
\text { - Low cost. } \\
\text { - Little variability on spheroids' size. } \\
\text { - } \text { Quick production of spheroids. }\end{array}$ & $\begin{array}{l}\text { - It is not suitable to large volumes. } \\
\text { - Uncontrollable expansion of } \\
\text { spheroids. }\end{array}$ \\
\hline Forced floating & $\begin{array}{l}\text { - Relatively simple. } \\
\text { - Low cost. } \\
\text { - Homogen and consistant spheroids. } \\
\text { - Suitable for assays to monitor drug } \\
\text { cytotoxicity. }\end{array}$ & - It is not a fast method. \\
\hline Bioreactor & $\begin{array}{l}\text { - Applicable to large scale production. } \\
\text { - Best distribution of nutrients through } \\
\text { media. } \\
\text { - Cells are cultured during long } \\
\text { periods. }\end{array}$ & $\begin{array}{l}\text { - Spheroids' size is not uniform. } \\
\text { - It requires specific pieces of } \\
\text { equipment. } \\
\text { - Depending on the reactor type, the } \\
\text { high shear force can affect spheroids' } \\
\text { physiology. }\end{array}$ \\
\hline Scaffolds & $\begin{array}{l}\text { - Large variety of materials. } \\
\text { - Intermediate cost. } \\
\text { - It is close to cells' } \\
\text { environment. }\end{array}$ & $\begin{array}{l}\text { - High cost if used in large scale. } \\
\text { - It requires specific pieces of } \\
\text { equipment to be manufactured. }\end{array}$ \\
\hline Matrix & $\begin{array}{l}\text { - Large variety of materials. } \\
\text { - It is close to cells' } \\
\text { environment. }\end{array}$ & $\begin{array}{l}\text { - It allows cells superposing one } \\
\text { another. } \\
\text { - High cost of gels and reactants. }\end{array}$ \\
\hline
\end{tabular}

Font: Adapted from Breslin and O’Driscoll (2013).

\section{Cancer treatments}

Cancerous tissues are heterogeneous and, particularly, contain several subpopulations of neoplastic cells that differ in functional properties, such as growth rate, metastasis and sensibility to drugs. Besides, isolated subpopulation (obtained through monolayer culture) do not reflect the complex nature of the environment where tumors are found, and thus, chemical compounds' performance results obtained from experiments carried out in these systems lead to erroneous conclusions, mostly. That has been shown by Mina Bissell' works (Dutta and Dutta, 2009).

She formulated the dynamic reciprocity theory which states that ECM 
would send signals to cell's nucleus, resulting in changes (reshape) in the chromatin and expression of genes, then, the nucleus would send signals back, reshaping the ECM (Dutta and Dutta, 2009).

This three-dimensional cellular model of mammary gland was adapted to create a protocol that differentiated normal cells from malignant ones (Weaver et al., 1997). Therefore, by using materials adequate to 3D cell culture, one can significantly improve the accuracy of diagnosis in cancer treatment (Dutta and Dutta, 2009).

\section{possibilities \\ Bioprocess engineers and its}

Engineering is a science that applies knowledge and techniques to create and improve products, taking into account society, economy and environment. Currently, engineering covers several fields according to different types of technology (CREA-RN, 2013).

Bioprocess Engineers is a branch of engineering whose professional has expertise in the fields of chemistry, physics, mathematics, computational methods and biology, and is qualified to develop and perfect biotechnological processes and products. Bioprocess engineers use natural or genetically modified organisms, as well as their parts (enzymes, for example) to manufacture, in industrial scale, products that meet society's needs (PPC Engenharia de Bioprocessos, UFSJ, 2010).

Some areas where such engineer can work are: environment, clean technology, additives for food industry, bioenergy food and drinks, fertilizers, microbial inoculums for agriculture and industry, kits for diagnosis, biopolymers, enzymes for chemical and pharmaceutical industries, vaccines, antibiotics, bioactive proteins and other biopharmaceuticals (PPC - Engenharia de Bioprocessos, UFSJ, 2010).

\section{Challenges for Bioprocess Engineers in $3 \mathrm{D}$ culture cells}

Bioprocess engineers are one of the most qualified professionals to develop technology and manage production in 3D cell culture, since they can plan the production process aware of cell behavior according to changes on process variables. It was shown that three-dimensional cell culture has appeared to revolutionize researches on cancer, tissue engineering and drug screening and it is a promising technique for biologicals in large scale.

In order to develop the above-cited processes is necessary that both engineering and life science knowledge be truly integrated.

One example of that is demonstrated by the worked carried out by Chouinard et al. (2009). They developed a whole bioreactor system (including data acquisition, bioreactor, pumps, gas exchange unit and heat exchanger) for high human umbilical vein endothelial cells density. The system monitored and controlled many parameters, such as $\mathrm{pH}$, flow rate, pulsation and temperature, in real time and provided a good system to produce cells in vitro and in large scale.

In tissue engineering, for example, engineering knowledge must be employed to develop scalable reactor that present satisfactory mass and heat transfer in sterile environment that overcomes the challenges of restrict flow passage throughout porous scaffolds; such reactors should also have adequate data acquisition and probes to monitor the process, and therefore guarantee standardization, as well as quality of productive process.

Another engineering aspect of tissue production process would be the fabrication of three-dimensional scaffold, with biocompatible and biodegradable material, which mimics human system; although it has successfully been obtained through 3D printing, scalability and cost of 
this technique must be evaluated for industrial tissue production. On top of that, bioprocess engineers should have deep understanding of target cell's metabolism and behavior to design both bioreactor and scaffold, based on the final product to be obtained.

According to what have been discussed so far, one bottleneck to be overcome is the scale up of mammalian cell culture. Before starting the scaling process, one should know adequate/optimum values of some parameters that are critical to 3D cell culture, such as stirring, aeration, temperature, $\mathrm{pH}$, volumetric mass transfer coefficient, shear force, cell specific growth rate, and others. Depending on the final product, downstream step may also be a big challenge and affect the choice of previous unit operations. For example, whether cell is the target product, cons and pros of spheroid cultivation (in STR or wave bioreactors, for example) versus supportbased cell culture (packed-bed, HBF) should be carefully analyzed, since the latter implies the use of conditions (enzymes, chelating agent) that may reduce cell viability. On the other hand, if the products are mammalian cell biomolecules excreted in the media, packed-bed and hollow fiber reactors, and STR with microcarriers could make further purification steps easier, since great part of cells is retained in the solid surface.

Since these properties are identified and determined, the system can be scaled up, provided that such properties are kept in the new scale. It is also important that geometric similarity of bioreactors is preserved from one scale to another in order to obtain similar yields in large scale (Schmidell et al., 2001).

To optimize these processes or even predict cells responses to environmental stimulus during cell culture, an important tool well known by bioprocess engineers is process modeling and simulation, which saves time and reduces the number of empirical attempts during optimization process. Magrofuoco et al. (2012), for example, modeled and simulated the cellular response of cells to glucose into porous scaffold by using mass transport phenomena equations and found that flow rate affect cells responses. Computational Fluid Dynamics is simulation tool that has been widely used to predict best operational conditions in mammalian cell culture bioreactors (Weyand et al., 2009)

This tool is very important in 3D cell culture, especially in co-cultures, where the modeling of the cells behavior could predict if they would acquire a tissue design, what would be very interesting. However, this process is difficult due to the systemic characteristic of cellular biology, that can be seen as a group of interdependent elements that interact with one another with a common objective, and where each element acts as a system itself (Alvarez, 1990).

The science from the previous century adopted classical mechanics as model for scientific thinking, that is, phenomena were interpreted as close mechanism and system. Nowadays, science uses a living organism as model, that is, phenomena are studied as open and dynamic systems which offer higher degree of complexity to the modeling process.

In addition, designing pieces of equipment specific for 3D cell culture and automate them, as HTS Technology does, is one of the abilities of bioprocess engineers.

\section{Conclusion}

According to Cohen (2004), "mathematics is the next microscope of biology, but better; biology is the next physics of mathematics, but better". Biology provides new problems that stimulate mathematics to reinvent itself to solve those problems. The Bioprocess Engineer seems to be the bridge between both fields.

Projecting 3D cell culture in large scale without affecting basic characteristics of the culture, creating new materials that are biocompatible with cells, developing automated equipment for cell culture to avoid mistakes during the process (contamination, for example), obtaining new methods that resemble more and more cells' natural environment, reducing process costs and its yield are challenges to 
be overwhelmed and bioprocess engineers have the tools and knowledge to do so.

\section{Conflict of interest statement}

Authors declare that they have no conflict of interests.

\section{References}

Andrei, G. Three-dimensional culture models for human viral diseases and antiviral drug development. Antiviral Research, v. 71, no. 2/3, p. 96-107, 2006. http://dx.doi.org/10.1016/j.antiviral.2006.05.023

Alvarez, M. E. B. Organização, sistemas e métodos. 5 ed. São Paulo: McGraw-Hill, 1990.

Alves, E. A.; Guimarães, A. C. R. Cultivo celular. In: Molinaro E. M. (Ed.). Conceitos e métodos para a formação de profissionais em laboratórios de saúde. Rio de Janeiro: EPSJV, 2010. p. 215-254.

Amaral, J. B.; Machado-Santelli, G. M. A cultura de células em 3 dimensões e a sua aplicação em estudos relacionados a formação do lúmen. Naturalia, v. 34, p. 1-20, 2011. Available from: <http://www.periodicos.rc. biblioteca.unesp.br/index.php/naturalia/article/ view/4399/3600>. Accessed on: Aug. 17, 2016.

Amaral, J. B. Células MCF-7 como modelo 3D no estudo de câncer de mama humano. São Paulo: Universidade de São Paulo, 2010. (Thesis of doctorat).

Astashkina, A.; Grainger, D. W. Critical analysis of 3-D organoid in vitro cell culture models for high-throughput drug candidate toxicity assessments. Advanced Drug Delivery Reviews, v. 69-70, p. 1-18, 2014. http://dx.doi.org/10.1016/j.addr.2014.02.008

Baradez, M.-O.; Marshall, D. The use of multidimensional image-based analysis to accurately monitor cell growth in 3D bioreactor culture. Plos One, v. 6, no. 10, p. 1-12, 2011. http://dx.doi.org/10.1371/journal.pone.0026104

Barbosa, B. S.; Santo, F. A.; Pimentel, M. M. L.; Fernandes, D. P.; Prexedes, E. A.; Bezerra, M. B. Histórico do desenvolvimento do cultivo de animais. Uma revisão. Revista Brasileira de Higiene e Sanidade Animal, v. 9, no. 2, p. 334347, 2015. http://dx.doi.org/10.5935/19812965.20150032
Breslin, S.; O’Driscoll, L. Three-dimensional cell culture: the missing link in drug discovery. Drug Discovery Today, v. 18, no. 5/6, p. 240249，2013. https://dx.doi.org/10.1016/j.drudis. 2012.10.003

Brown, B. N.; Badilak, S. F. Extracellular matrix as an inductive scaffold for functional tissue reconstruction. Translational Research, v. 163, no. $4, \quad$ p. 268-285, 2014. https://dx.doi.org/10.1016/j.trsl.2013.11.003

Burg, K. J. L.; Porter, S.; Kellam, J. F. Biomaterial developments for bone tissue engineering. Biomaterials, v. 21, no. 23, p. 2333-2492, 2000. http://dx.doi.org/10.1016/ S0142-9612(00)00102-2

Byrnes, W. M. Ernest Everett Just, Johannes Holtfreter, and the origin of certain concepts in embryo morphogenesis. Mol. Reprod. Dev., $\begin{array}{llll}\text { v. } 76, & \text { no. } 10, & \text { p. } 912-921, & \end{array}$ https://dx.doi.org/10.1002/mrd.21081

Carrel, A. On the permanent life of tissues outside of the organism. Journal of Experimental Medicine, v. 15, no. 5, p. 516528, 1912. Available from: $<$ https://www.ncbi.nlm.nih.gov/pmc/articles/ PMC2124948/>. Accessed on: Aug. 17, 2016.

Carvalho, A. C. A.; Pereira, E. S. C.; Costa, C.; Barreto, I. C.; Madureira, L. C.; Paim, F. R. Estratégias regenerativas da bioengenharia tecidual e aspectos éticos. Revista de Ciências Médicas e Biológicas, v. 9, no. 1, p. 20-27, $2010 . \quad$ Available from: $<$ https://portalseer.ufba.br/index.php/cmbio/artic le/view/4728/3501>. Accessed on: Aug. 17, 2016.

Chouinard, J. A.; Gagnon, S.; Couture, M. G.; Lévesque, A.; Vermette, P. Design and validation of a pulsatile perfusion bioreactor for 3D high cell density cultures. Biotechnology and Bioengineering, v. 104, no. 6, p. 12151223, 2009. https://dx.doi.org/10.1002/bit.22477

CREA-RN - Conselho Regional de Engenharia e Agronomia do Rio Grande do Norte. História da Engenharia. Available from: $<$ http://www.crea-rn.org.br/artigos/ver/120>. Accessed on: Ago. 17, 2016.

Cohen, S. Social relationships and health. Am. Physicol., v. 59, no. 8, p. 679-684, 2004.

Dhaliwal, A. Three dimensional cell culture: a review. Materials and Methods, v. 2, p. 1-16, 2012. 
Doran, P. M. Bioprocess engineering principles. 2. ed. London: Elsevier, 1995.

Dutta, R. C.; Dutta, A. K. Cell-interactive 3Dscaffold; advances and applications. Biotechnology Advances, v. 27, no. 4, p. 334339, 2009. http://dx.doi.org/10.1016/j.biotechadv. 2009.02.002

Elliott, N. T.; Yuan, F. A review of threedimensional in vitro tissue models for drug discovery and transport studies. Journal of Pharmaceutical Science, v. 100, no. 1, p. 5974, 2010. http://dx.doi.org/10.1002/jps.22257

Elsdale, T., Bard, J. Collagen substrata for studies on cell behavior. The Journal of Cell Biology, v. 54, no. 3, p. 626-637, 1972. http://dx.doi.org/10.1083/jcb.54.3.626

Fennema, E.; Rivron, N.; Rouwkema, J.; Blitterswijk, C. V.; Boer, J. Spheroid culture as a tool for creating 3D complex tissues. Trend in Biotechnology, v. 31, no. 2, p. 108-115, 2013. http://dx.doi.org/10.1016/j.tibtech.2012.12.003

Garcia-Ochoa, F.; Santos, V. E.; Gomez, E. Stirred tank bioreactors. In: Moo-Young, M. (Ed.). Comprehensive biotechnology: engineering fundamentals of biotechnology. 2. ed. London: Elsevier, 2011. v. 2. p. 179-198.

GE Healthcare Life Science. Bioprocessing Bioreactors. Available from: $<$ http://www.gelifesciences.com/webapp/wcs/store s/servlet/catalog/en/GELifeSciences-br/products/ AlternativeProductStructure_24445/>. Accessed on: Jul. 05, 2016.

Goepfert, C.; Scheurer, W.; Rohn, S.; Rathjen, B.; Meyer, S.; Dittmann, A.; Wiegandt, K.; Janben, R.; Pörtne, R. 3D-bioreactor culture of human hepatoma cell line HepG2 as a promising tool for in vitro substance testing. BMC Proceedings, v. 5, no. 8, p. 15-18, 2011. http://dx.doi.org/10.1186/1753-6561-5-S8-P61

Haycock, J. W. (Ed.). 3D cell culture: methods and protocols. 1. ed. Sheffield: Humana Press, 2011. v. 695. (Methods in Molecular Biology.) http://dx.doi.org/10.1007/978-1-60761-984-0

Hsiao, A. Y.; Tung, Y. C.; Qu, X.; Patel, L. R.; Pienta, K. J.; Takayama, S. 384 hanging drop arrays give excellent $\mathrm{z}$-factors and allow versatile formation of co-culture spheroid. Biotechnology and Bioenginnering, v. 109, no. 5, p. 1293-1304, 2012. http://dx.doi.org/10.1002/bit.24399

Ivascu, A.; Kubbies, M. Rapid generation of single-tumor spheroids for high-throughput cell function and toxicity analysis. J. Biomol. Screen., v. 11, no. 8, p. 922-932, 2006. http://dx.doi.org/10.1177/1087057106292763
Santos Junior, A. R.; Wada, M. L. F. Polímeros biorreabsorvíveis como substrato para cultura de células tecidual. Polímeros: Ciência e Tecnologia, v. 17, no. 4, p. 308-317, 2007. http://dx.doi.org/10.1590/S010414282007000400010

Justice, B. A.; Bard, N. A; Felder, R. A. 3D cell culture opens new dimensions in cell-based assays. Drug Discovery Today, v. 14 , no. $1 / 2$, p. 102-107, 2009 . http://dx.doi.org/10.1016/j.drudis.2008.11.006

Kelm, J. M.; Timmins, N. E.; Brown, C. J.; Fussenegger, M.; Nielsen, L. K. Method for generation of homogeneous multicellular tumor spheroids applicable to a wide variety of cell types. Biotechnology and Bioengineering, v. 83, no. 2, p. 73-180. 2003. http://dx.doi.org/10.1002/bit.10655

Kumar, A. Starly, B. Large scale industrialized cell expansion: producing the critical raw material for biofabrication processes. Biofabrication, v. 7, p. 1-14, 2015.

Kurosawa, H. Methods for inducing embryoid body formation: in vitro differentiation of embryonic stem cells. Journal of Bioscience and Bioengineering, v. 103, no. 5, p. 389-398, 2007. http://dx.doi.org/10.1263/jbb.103.389

Kuystermans, D.; Al-Rubeai, M. Bioreactor systems for producing antibody from mammalian cells. In: Al-Rubeai, M. (Ed.). Antibody expression and production, cell engineering 7. Dublin: Springer, 2011.

Lee, J.; Cuddihy, M. J.; Kotov, N. A. Threedimensional cell culture matrices: state of the art. Tissue Engineering: Part B, v. 14, no. 1, p. 61-87, 2008. http://dx.doi.org/10.1089/ teb.2007.0150

Li, X. J.; Valadez, A. V.; Zuo, P.; Nie, Z. Microfluidic 3D cell culture: potential application for tissue-based bioassays. Bioanalysis, v. 4, no. 12, p. 1509-1525, 2012. https://dx.doi.org/10.4155/bio.12.133

Lin, R. Z.; Chang, H. Y. Recent advances in three-dimensional multicellular spheroid culture for biomedical research. Biotechnology Journal, v. 3, no. 9/10, p. 1172-1784, 2008. http://dx.doi.org/10.1002/biot.200700228

Lowe, S. B.; Tan, V. T. G.; Soeriyadi, A. H.; Davis, T. P.; Gooding, J. J. Synthesis and highthroughput processing of polymeric hydrogels for 3D cell culture. Bioconjugate Chemistry,

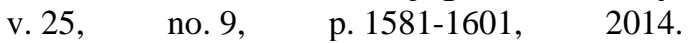
http://dx.doi.org/10.1021/bc500310v 
Luisi, S. B.; Barbachan, J. J. D.; Chies, J. A. B.; Sant'Ana Filho, M. A cultura de células como ferramenta para estudos do comportamento pulpar. Revista da Faculdade de Odontologia, v. 45, no. 1, p. 3-8, 2004. Available from: $<$ http://seer.ufrgs.br/index.php/RevistadaFaculd adeOdontologia/article/view/7676/9780>.

Accessed on: Jul. 05, 2016.

Magrofuoco, E.; Elvassore, N. Theoretical analysis of insulin-dependent glucose uptake heterogeneity in 3D bioreactor cell culture. Biotechnol. Prog., v. 28, no. 3, p. 833-845, 2012. http://dx.doi.org/10.1002/btpr.1539

Maltman, D. J.; Przyborski, S. A. Developments in three-dimensional cell culture technology aimed at improving the accuracy of in vitro analyses. Biochemical Society Transactions,

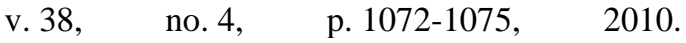
http://dx.doi.org/10.1042/BST0381072

Martin, Y.; Vermette, P. Bioreactors for tissue mass culture: design, characterization, and recent advances. Biomaterials, v. 26, no. 35, p. 7481-7503, 2005. http://dx.doi.org/10.1016/j.biomaterials.2005.05.057

Moraes, A. M.; Augusto, E. F. P.; Castilho, L. R. Tecnologia do cultivo de células animais: de biofármacos a terapia gênica. 1. ed. São Paulo: Roca, 2007.

Pampaloni, F.; Reynaud, E. G.; Stelzer, E. H. K. The third dimension bridges the gap between cell culture and live tissue. Nature Reviews, v. 8, p. 839-845, 2007. http://dx.doi.org/10.1038/nrm2236

Ravi, M.; Paramesh, V.; Kaviya, S. R.; Anuradha, E.; Solomon, F. D. P. 3D Cell Culture Systems: advantages and applications. Journal of Cellular Physiology, v. 230, p. 1626, 2015. http://dx.doi.org/10.1002/jcp.24683

Rozario, T.; DeSimone, D. W. The extracelular matrix in development and morphogenesis: a dynamic view. Developmental Biology, v. 341, no. 1, $\quad$ p. 126-140, 2010. http://dx.doi.org/10.1016/j.ydbio.2009.10.026

Sailon, A. M.; Allori, A. C.; Davidson, E. H.; Reformat, D. D.; Allen Jr., R. J.; Warren, S. M. A novel flow-perfusion bioreactor supports 3D dynamic cell culture. Journal of Biomedicine and Biotechnology, v. 2009, Article ID 873816, 7 p., 2009. http://dx.doi.org/10.1155/2009/873816

Schaeffer, I. W. In memorium: A tribute to Dr. Joseph Leighton. Methods in Cell Science, v. 21, no. 1, p. 1-4, 1999. http://dx.doi.org/10.1023/A:1009731524406
Schimidell, W.; Lima, U. A.; Aquarone, E.; Borzani, W. Biotecnologia Industrial: Engenharia Bioquímica. 1. ed. São Paulo: Edgard Blücher, 2001.

Sodunke, T. R.; Turner, K. K, Caldwell, S. A.; McBride, K. W.; Reginato, M. J.; Noh, H. M. Micropatterns of matrigel for three-dimensional epithelial cultures. Biomaterials, v. 28, no. 27, p. 4006-4016, 2007. http://dx.doi.org/10.1016/ j.biomaterials.2007.05.021

Souza, W. F. Perda de adesão célula-célula mediada pela e-caderina em câncer coloretal: vias de sinalização envolvidas. Rio de Janeiro: Instituto Nacional do Câncer, 2009. (Undergraduate dissertation).

Tavares, V. A. C. D. B. Matrizes de policaprolactona e quitosano para aplicação em engenharia de tecidos. Lisboa: Universidade Nova de Lisboa, 2011. (Undergraduate dissertation).

Tung, Y. C.; Hsiao, A. Y.; Allen, S. G.; Torisawa, Y.; Ho, M.; Takayama, S. Highthroughput 3D spheroid culture and drug testing using a 384 hanging drop array. Analyst., v. 136, no. 3, p. 473-478, 2011. http://dx.doi.org/10.1039/c0an00609b

Vinci, M.; Gowan, S.; Boxall, F.; Patterson, L.; Zimmermann, M.; Court, W.; Lomas, C.; Mendiola, M.; Hardisson, D.; Eccles, S. Advances in establishment and analysis of three dimensional tumor spheroid-based functional assays for target validation and drug evaluation. BMC Biology, 10:29, 20 p., 2012. http://dx.doi.org/10.1186/1741-7007-10-29

Weaver, V. M.; Petersen, O. W.; Wang, F.; Larabell, C. A.; Briand, P.; Damsky, C.; Bissell, M. J. Reversion of the malignant phenotype of human breast cells in three-dimensional culture and in vivo by integrin blocking antibodies. The Journal of Cell Biology, v. 137, no. 1, p. 231245, 1997. http://dx.doi.org/10.1083/jcb.137.1.231

Wendt, D.; Riboldi, S. A.; Cioffi, M.; Martin, I. Potential and bottlenecks of bioreactors in 3D cell culture and tissue manufacturing. Advanced Materials, v. 21, p. 3352-3367, 2009. http://dx.doi.org/10.1002/adma.200802748

Weyand, B.; Israelowitz, M.; Schroeder, H. P.; Vogt, P. M. Fluid dynamics in bioreactor design: considerations for the theoretical and practical approach. In: Kasper, C.; van Griensven, M.; Pörtner, R. (Eds.). Bioreactor Systems for Tissue Engineering. Heidelberg: Springer, 2009. http://dx.doi.org/10.1007/ 10_2008_13 
Williams, J. A. Keys to bioreactor selection. CEP Magazine, p. 34-41, March 2002.

Winkenwerder, J. J.; Palechek, P. L.; Reece, J. S.; Saarinen, M. A.; Arnold, M. A.; Cohen, M. B.; Murhammer, D. W. Evaluating prostate cancer cell culturing methods: a comparison of cell morphologies and metabolic activity. Oncol. Rep., v. 10, no. 4, p. 783-789, 2003. http://dx.doi.org/10.3892/or.10.4.783

License information: This is an open-access article distributed under the terms of the Creative Commons Attribution License, which permits unrestricted use, distribution, and reproduction in any medium, provided the original work is properly cited. 